\title{
PENGARUH MOTIVASI KERJA DAN KEMAMPUAN KERJA TERHADAP KINERJA KARYAWAN DI HOTEL GRAN SURYA SERIRIT
}

\author{
G. A. Nareswara ${ }^{1}$, Trianasari ${ }^{2}$ \\ 1,2Jurusan Manajemen, Universitas Pendidikan Ganesha, Singaraja \\ e-mail: adityanareswara5@gmail.com, nanatrianasari01@gmail.com
}

\begin{abstract}
Abstrak
Penelitian ini bertujuan untuk menguji pengaruh: (1) motivasi kerja terhadap kinerja karyawan, (2) kemampuan kerja terhadap kinerja karyawan, (3) motivasi kerja terhadap kemampuan kerja, dan (4) motivasi kerja terhadap kinerja karyawan melalui kemampuan kerja di Hotel Gran Surya Seririt. Desain penelitian yang digunakan dalam penelitian ini adalah kuantitatif kausal. Objek penelitian ini adalah motivasi kerja, kemampuan kerja dan kinerja karyawan. Subjek penelitian adalah seluruh karyawan Hotel Gran Surya Seririt dengan jumlah populasi sebanyak 32 orang. Data dikumpulkan menggunakan kuesioner dan dianalisis dengan analisis jalur. Hasil penelitian menunjukkan bahwa: (1) motivasi kerja berpengaruh positif dan signifikan terhadap kinerja karyawan (2) kemampuan kerja berpengaruh positif dan signifikan terhadap kinerja karyawan, (3) motivasi kerja berpengaruh positif dan signifikan terhadap kemampuan kerja dan (4) motivasi kerja berpengaruh positif dan signifikan terhadap kinerja karyawan melalui kemampuan kerja.
\end{abstract}

Kata-kata kunci: hotel, kinerja karyawan, kemampuan kerja, motivasi kerja

\begin{abstract}
This study aims to examine the effects of: 1) motivation on employee performance, (2) capability on employee performance, (3) motivation on capability and (4) motivation on employee performance through capability at Gran Surya Seririt Hotel. Research design used in this study was quantitative causal. The research subjects were all employees of Gran Surya Seririt Hotel with a population of 32 people. Data were collected using questionnaire and were analyzed using path analysis. The results showed that: (1) motivation has a positive and significant effect on employee performance (2) capability has a positive and significant effect on employee performance (3) motivation has a positive and significant effect on capability and (4) motivation has a positive and significant effect on employee performance through capability at Gran Surya Seririt Hotel.
\end{abstract}

Keywords: hotel, employee performance, motivation, work ability

\section{Pendahuluan}

Sumber daya manusia (SDM) mempunyai sebuah peran penting terhadap pencapaian sebuah target perusahaan, karena SDM merupakan faktor penggerak sumber daya lainnya. Menurut Bangun (2012) bahwa SDM mempunyai sebuah peran penting guna tercapainya sebuah target perusahaan. Keberhasilan perusahaan dalam mengelola SDM diukur menggunakan kinerja karyawan yang dipengaruhi oleh motivasi dan kemampuan kerja. Menurut Sulistiyani (2003) jika sebuah motivasi tinggi kemudian diimbangi dengan kemampuan yang baik maka kinerja pekerja akan tinggi begitu pula sebaliknya. Hal ini juga dipertegas oleh hasil penelitian dari Muliharta (2015).

Kegiatan operasional hotel tidak terlepas dari evaluasi hasil kerja dan pengelolaan SDM yang berperan sebagai pemberi layanan sebagaimana organisasi lainnya. Demikian pula, kemampuan dan motivasi karyawan hotel perlu dianalisis karena berkaitan dengan kinerja. Seiring dengan pertumbuhan industri pariwisata, perkembangan hotel juga semakin meningkat. Berdasarkan riset awal yang telah dilakukan terhadap tiga hotel berbintang tiga yang berada di Kabupaten Buleleng adalah data tingkat hunian kamar dari tiga hotel tersebut yaitu Hotel Aneka, Hotel Puri Saron dan Hotel Gran Surya. Rata-rata tingkat hunian kamar 
Hotel Gran Surya paling rendah hanya sebesar $14 \%$, dibandingkan dua hotel lainnya yaitu Hotel Aneka mencapai 30\% dan Hotel Puri Saron mencapai 56\%. Hotel Gran Surya yang terletak di Seririt merupakan badan usaha yang bergerak di bidang akomodasi yang menunjang akses untuk mempermudah berwisata. Hotel ini merupakan hotel bintang tiga yang menyediakan 37 kamar dan memiliki 32 karyawan yang masih aktif. Rendahnya tingkat hunian kamar di Hotel Gran Surya diduga karena kinerja karyawan hotel yang masih belum optimal sehingga tujuan dari hotel belum dapat tercapai. Kinerja adalah segala pencapaian yang diperoleh individu dalam menjalankan beban yang ditugaskan terhadapnya dimana didasari oleh keuletan, dan waktu (Hasibuan, 2001).

Kinerja Hotel secara menyeluruh dapat dipengaruhi oleh kinerja karyawan. Dalam literatur SDM, kinerja karyawan dipengaruhi oleh motivasi dan kemampuan kerja. Berdasarkan hasil wawancara yang dilakukan di Hotel Gran Surya, motivasi karyawan masih tergolong rendah. Hal ini berpotensi disebabkan karena penghargaan yang diberikan kepada karyawan masih sangat sedikit, di samping itu hubungan antar karyawan terbilang buruk didukung dengan kondisi kerja kurang nyaman menyebabkan motivasi pekerja menjadi rendah. Selain motivasi kerja, yang mampu membuat kinerja pekerja kurang karena kemampuan yang dimiliki karyawan masih tergolong rendah. Kemampuan karyawan di Hotel Gran Surya masih tergolong rendah dilihat dari kemampuan intelektual dan emosional karyawan. Pada kemampuan intelektual, karyawan belum memiliki inisiatif dalam mengevaluasi dan meningkatkan kinerja dengan strategi-strategi baru. Penguasaan informasi karyawan masih kurang sehingga informasi yang diberikan kurang cepat dan tepat yang menyebabkan pelayanan belum optimal sedangkan dalam kemampuan emosional karyawan masih belum percaya diri dalam berkomunikasi berbahasa Inggris dan keahlian lain yang dibutuhkan dalam bidangnya sehingga banyak terjadi keluhan dari wisatawan. Selain itu keinginan karyawan untuk saling membantu dan melayani sangat kurang sehingga hal tersebut menyebabkan kondisi dan lingkungan kerja yang kurang kondusif dan seharusnya karyawan mampu beradaptasi dalam segala keadaan dan kebutuhan dari wisatawan maupun rekan kerja.

Fakta-fakta permasalahan ini mengindikasikan bahwa Hotel Gran Surya perlu informasi empirik mengenai motivasi kerja, kemampuan kerja dan kinerja karyawan serta pengaruhnya yang nantinya dipergunkan untuk pertimbangan dalam pengambilan keputusan, pemecahan masalah yang dihadapi oleh karyawan. Sejauh ini manajemen Hotel Gran Surya belum melakukan riset internal terkait hal tersebut. Sementara itu, menurut Sulistiyani (2003) jika dorongan tinggi ditunjang dengan ilmu yang tinggi maka kinerjapekrja akan tinggi begitu sebaliknya. Berdasarkan fenomena yang terjadi di Hotel Gran Surya maka penelitian berfokus pada pengaruh motivasi dan kemampuan kerja terhadap kinerja karyawan di Hotel Gran Surya Seririt.

Tujuan penelitian ini adalah untuk menguji pengaruh (1) motivasi kerja terhadap kinerja karyawan; (2) kemampuan kerja terhadap kinerja karyawan; (3) motivasi kerja terhadap kemampuan kerja, dan (4) motivasi kerja terhadap kinerja karyawan melalui kemampuan kerja di Hotel Gran Surya Seririt.

Hubungan variabel $X_{1}$ Terhadap variabel $Y$, variabel $X_{1}$ berpengaruh terhadap variabel $Y$ karena apabila pekerja mendapatkan dorongan yang kuat maka pekerja akan termotivasi untuk giat bekerja sehingga berdampak terhadap kinerja karyawan. Robbin (2002) mengemukakan bahwa motivasi adalah kegigihan untuk melaksanakan setengah kemauan individual. Sedangkan Hasibuan (2005) menyatakan motivasi diartikan dorongan untuk memunculkan gairah kerja pekerja agar pekerja mampu kerja secara baik. Indikator motivasi yang digunakan indikator dikemukakan oleh Sutrisno (2010) yaitu (1) motivasi intrinsik meliputi (1) prestasi yang artinya hasil atas usaha yang dilakukan oleh seorang karyawan yang bersungguh-sungguh dalam bekerja, (2) penghargaan artinya pemberian dalam bentuk mendali, piala, penghargaan, dan sertifikat kepada karyawan yang berkontribusi lebih terhadap perusahaan, (3) pekerjaan sendiri artinya sikap karyawan terhadap karakteristik pekerjaan dalam mengerjakan tugas yang diberikan kepadanya, (4) tanggung jawab artinya 
keadaan dimana seorang karyawan wajib menanggung segala sesuatu dalam pekerjaannya, (5) promosi artinya berkesempatan untuk melangkah lebih baik dalam karier.

Hubungan motivasi kerja dengan kinerja karyawan disampaikan oleh Rivai (2004) yang menyatakan bahwa semakin kuat motivasi kerja maka kinerja karyawan akan semakin tinggi. pernyataan tersebut didukung oleh penelitian empirik dari Amalia (2018). Berdasarkan landasan teori dan hasil penelitian sebelumnya maka hipotesis penelitian yang diajukan adalah:

$\mathrm{H}_{1}$ : Ada pengaruh $\mathrm{X}_{1}$ terhadap $\mathrm{Y}$ di Hotel Gran Surya Seririt

Hubungan Kemampuan Kerja terhadap Kinerja Karyawan, Kemampuan kerja berdampak pada sebuah kinerja karyawan karena semakin baiknya skill pekerjan maka akan semakin tinggi pula kinerja yang diberikan. Kemampuan kerja adalah individu yang memiliki sebuah keuletan pada saat menyelesaikan segala hal, dan diselesaikan berdasarkan sebuah tindakan guna memaksimalkan pekerjaannya. Kemampuan adalah sebuah kapasitas seseorang dalam menyelesaikan segala beban pekerjaan (Robbins, 2002).

Wursanto (2003) menyatakan bahwa kemampuan kerja adalah kecekatan individu, mencangkup kepintaran dan kelugesannya dalam menyelesaikan segala permasalahan yang didapatkan. Kemampuan kerja menggambarkan kecekatan individu yaitu kepintaran. Menurut Spencer \& Spencer (1993) indikator kemampuan kerja yaitu: (1) kemampuan intelektual yang artinya kesanggupan seseorang yang bersifat stabil pada saat ia mendapatkan sebuah masalah pada saat bekerja. Kemampuan ini sangat dibutuhkan dalam menghadapi permasalahan yang ada baik yang berasal dari internal maupun eksternal perusahaan. (2) kemampuan emosional yang artinya keterampilan dalam mengontrol diri dan mengerti ketika menyelesaikan sebuah masalah pada saat bekerja. (3) kemampuan sosial artinya keterampilan dalam mengembangkan kiat-kiat dalam bekerja bersama-sama dengan rekan kerja dalam satu ruang lingkup yang sama. (4) kemampuan spiritual yang artinya kesadaran yang dimiliki individu yang terhubung dengan keyakinan yang bersumber dari individu tersebut.

Hubungan kemampuan kerja terhadap kinerja karyawan disampaikan oleh Martoyo (2006) yang menjelaskan bahwa semakin baik kemampuan kerja karyawan maka semakin tinggi pula kinerja karyawan. Pernyataan tersebut didukung oleh empirik Arini (2015). Hipotesis penelitian yang diajukan adalah:

$\mathrm{H}_{2}$ : Ada pengaruh $X_{2}$ terhadap $Y$ di Hotel Gran Surya Seririt

Hubungan $\mathrm{X}_{2}$ terhadap $\mathrm{Y}, \mathrm{X}_{2}$ berpengaruh terhadap $\mathrm{Y}$ karena dengan memberikan dorongan yang maksimal maka seorang pekerja akan termotivasi dalam memaksimalkan kemampuannya. Menurut Suranta (2002) motivasi merupakan perasaan yang muncul pada diri individu sebagai dorongan karena timbulnya rangsangan dari luar yang berdampak dalam mencapai target perusahaan.

Hubungan motivasi kerja terhadap kemampuan kinerja disampaikan oleh Blumberg (1982) yang menyatakan karyawan yang memiliki motivasi akan berpengaruh terhadap kemampuan yang dimilikinya dan sebaliknya. Hipotesis penelitian yang diajukan adalah:

$\mathrm{H}_{3}$ : Ada pengaruh $\mathrm{X}_{1}$ terhadap $\mathrm{X}_{2}$ di Hotel Gran Surya Seririt

Hubungan $X_{1}$ terhadap $Y$ melalui $X_{2}$, Motivasi dan kemampuan kerja berpengaruh terhadap kinerja karyawan karena karyawan yang memiliki motivasi dan kemampuan yang tinggi akan dapat meningkatkan kinerjanya. Kinerja karyawan memiliki dua konsep yaitu output dan outcome. Hasibuan (2001) mengemukakan kinerja adalah segala pencapaian yang diperoleh individu dalam menjalankan beban yang ditugaskan terhadapnya dimana didasari oleh keuletan, dan waktu. Robbins (2008) menyatakan bahwa kinerja sebuah kapasitas seseorang dalam menyelesaikan segala beban pekerjaan.

Hubungan $X_{1}$ terhadap $Y$ melalui $X_{2}$ disampaikan oleh Sulistiyani (2003) menyatakan apabila apabila motivasi tinggi kemudian didukung oleh skill yang baik maka kinerja pegawai juga tinggi dan sebaliknya. Pernyataan tersebut didukung oleh penelitian empirik dari Muliharta (2015) menyimpulkan motivasi kerja dan kemampuan berpengaruh positif dan signifikan terhadap kinerja karyawan. Jadi dapat disimpulkan bahwa $X_{1}$ dan $X_{2}$ berpengaruh 
terhadap Y. Berdasarkan landasan teori dan hasil penelitian sebelumnya maka hipotesis penelitian yang diajukan adalah:

$\mathrm{H}_{4}$ : Ada pengaruh $\mathrm{X}_{1}$ terhadap $\mathrm{Y}$ melalui $\mathrm{X}_{2}$ di Hotel Gran Surya Seririt

\section{Metode}

Penelitian ini dilakukan untuk mengetahui pengaruh $X_{1}$ dan $X_{2}$ terhadap $Y$ pada Hotel Gran Surya Seririt. Menurut Sugiyono (2014: 39), variabel dalam penelitian terdiri dari variabel bebas dan variabel terikat. Dalam penelitian ini variabel bebas yaitu motivasi kerja dan kemampuan kerja. Sedangkan variabel terikatnya yaitu kinerja karyawan. Berdasarkan karakteristik masalah yang diteliti maka desain penelitian penelitian ini adalah desain kausal yang dapat meneliti korelasi antara variabel satu dan variabel lainnya. Desain penelitian kuantitatif kausal terdiri dari beberapa tahapan meliputi (1) merumuskan masalah, (2) mengkaji teori, (3) merumuskan hipotesis, (4) mengumpulkan data, (5) mengolah data, dan (6) menarik simpulan.

Subjek penelitian dalam penelitian ini adalah seluruh karyawan yang bekerja di Hotel Gran Surya Seririt, sedangkan objek penelitian ini adalah motivasi kerja $\left(X_{1}\right)$, kemampuan kerja $\left(X_{2}\right)$ dan kinerja karyawan $(Y)$ di Hotel Gran Surya Seririt. Populasi adalah seluruh elemen berbentuk kejadian, seseorang yang mempunyai sebuah ciri-ciri yang sama dapat dijadikan pusat perhatian penelitian (Ferdinand, 2006). Populasi adalah keseluruhan wilayah meliputi subjek dan objek yang mempunyai ciri tertentu oleh peneliti guna diteliti dan selanjutnya disimpulkan` (Sugiyono 2007: 72). Populasi dalam penelitian ini adalah banyaknya karyawan aktif di Hotel Gran Surya yang berjumlah 32 karyawan.

Pada penelitian ini prosedur pengumpulan data yang digunakan dalam penelitian adalah sebagai kuesioner. Kuesioner adalah instrumen pengumpulan data dengan kemungkinan jawaban pernyataan yang telah disiapkan dalam bentuk pilihan. Responden tidak perlu lagi memberikan tambahan jawaban, yang nantinya dapat memudahkan penelitian dalam menganalisis data. Skala yang paling banyak digunakan dalam penyusunan angket adalah skala likert, yaitu skala yang terdapat lima tingkat jawaban yang tersusun ke dalam bentuk daftar pertanyaan. Kuesioner dalam suatu penelitian tentu harus memenuhi syarat validitas dan reliabilitas. Dalam penelitian ini, pengujian instrumen dilakukan agar dapat memperoleh keakuratan data. Kuesioner dikatakan sah apabila kuesioner mampu untuk menggambarkan suatu hal yang diukur oleh kuesioner tersebut. Sebelum digunakan sebagai alat mengumpulkan data harus diuji cobakan terlebih dahulu. Uji coba tersebut dilakukan terhadap responden diluar sampel. Menurut Sugiyono (2007) instrument dinyatakan sah jika koefisien korelasi antar butir > dari 0,30 dengan tingkat kesalahan alpha 0,05. Sedangkan Uji reliabilitas bertujuan untuk mengetahui alat pengumpul data pada dasarnya menunjukkan tingkat ketepatan koesioner. Menurut Sugiyono (2007), kriteria suatu instrumen penelitian dikatakan reliabel adalah apabila koefisien reliabilitas $\left(r_{i}\right)>0,60$. Untuk membantu proses pengolahan data untuk uji validitas digunakanlah sebuah program komputer yang akan membantu dengan baik.

Analisis data dalam penelitian ini menggunakan path analysis. Analisis jalur dipergunakan guna menggambarkan model hubungan antar variabel yang berbentuk sebab akibat. Analisis jalur digunakan untuk mengetahui besarnya pengaruh total dan pengaruh langsung serta tidak langsung dari variabel $\mathrm{X}_{1}$ dan $\mathrm{X}_{2}$ terhadap $\mathrm{Y}$ di Hotel Gran Surya.

Langkah kerja pengolahan dan analisis data analisis jalur sebagai berikut, Mengolah data ordinal menjadi interval dengan metode interval berurutan baik untuk variabel $X_{1}$ dan $X_{2}$ maupun variabel $Y$ dengan cara: Mengambil data ordinal hasil kuesioner, Untuk setiap pernyataan, menghitung proporsi jawaban untuk setiap kategori jawaban dan hitung proporsi kumulatifnya, Menghitung nilai Z (tabel distribusi normal) untuk setiap proporsi kumulatif, data $\mathrm{n}>30$ dianggap mendekati luas daerah dibawah kurva normal, Menghitung nilai densitas untuk setiap proporsi komulatif dengan memasukkan nilai pada rumus distribusi normal, Menghitung nilai skala dengan rumus dari Hays (1969: 39) Means of interval. 
Menentukan nilai transformasi dengan menggunakan rumus:

Nilai Transformasi $=$ Nilai Skala + Nilai Skala Maksimum +1

\section{Hasil dan Pembahasan}

Berdasarkan hasil perhitungan uji statistik analisis jalur didapatlah sebuah hasil $\mathrm{Pyx}_{1}=$ 0,556 dengan $p$-value $=0,000<$ alpha 0,05 sehingga keputusannya adalah menolak Ho. Ini artinya motivasi kerja $\left(X_{1}\right)$ berpengaruh secara positif dan signifikan terhadap kinerja karyawan (Y) pada Hotel Gran Surya. Sumbangan pengaruh $X_{1}$ terhadap $Y$ sebesar 0,556 atau 55,6\% sehingga besar sumbangan pengaruh secara total $X_{1}$ terhadap $Y$ yaitu 0,779 atau $77,9 \%$.

Berdasarkan hasil perhitungan uji statistik analisis jalur didapatkan nilai $\operatorname{Pyx}_{2}=0,458$ dengan $p$-value $=0,000<$ alpha 0,05 sehingga keputusannya adalah menolak Ho. Ini artinya kemampuan kerja $\left(\mathrm{X}_{2}\right)$ berpengaruh secara positif dan signifikan terhadap $\mathrm{Y}$ pada Hotel Gran Surya. Sumbangan pengaruh $\mathrm{X}_{2}$ terhadap $\mathrm{Y}$ sebesar 0,458 atau $45,8 \%$.

Berdasarkan hasil perhitungan uji statistik analisis jalur didapatkan nilai $\mathrm{Px}_{2} \mathrm{x}_{1}=0,879$ dengan $p$-value $=0,000<$ alpha 0,05 sehingga keputusannya adalah menolak Ho. Ini artinya motivasi kerja berpengaruh secara positif dan signifikan terhadap kemampuan kerja pada Hotel Gran Surya. Besar sumbangan pengaruh $X_{1}$ terhadap $X_{2}$ adalah 0,879 atau $87,9 \%$.

Berdasarkan hasil perhitungan uji statistik analisis jalur diperoleh hasil $\mathrm{Px}_{2} \mathrm{x}_{1}=0,879$ dan Pyx $_{2}=0,458$ dengan $p$-value $=0,000<$ alpha 0,05 sehingga sumbangan pengaruh tidak langsung motivasi kerja terhadap kinerja karyawan melalui kemampuan kerja didapat dari pengalian $\mathrm{Px}_{2} \mathrm{X}_{1}$. $P \mathrm{Px}_{2}$ sehingga hasilnya sebesar 0,402 atau $40,2 \%$.

Output SPSS analisis jalur pengaruh $X_{1}$ dan $X_{2}$ terhadap $Y$ di Hotel Gran Surya Seririt nampak pada tabel 1.

\begin{tabular}{ccccc} 
Para meter & Koefisien & $\begin{array}{c}\text { P. } \\
\text { Value }\end{array}$ & $\begin{array}{c}\text { Alph } \\
\mathbf{a}(\boldsymbol{\alpha})\end{array}$ & Keputusan \\
\hline $\mathbf{R}_{\mathbf{2}} \mathbf{y \mathbf { x } _ { 1 } \mathbf { x } _ { 2 }}$ & 0,967 & 0,000 & 0,05 & Menolak Ho \\
$\mathbf{P y x}_{1}$ & 0,556 & 0,001 & 0,05 & Menolak Ho \\
$\mathbf{P y x}_{\mathbf{2}}$ & 0,458 & 0,000 & 0,05 & Menolak Ho \\
$\mathbf{P x}_{\mathbf{2}} \mathbf{x}_{\mathbf{1}}$ & 0,879 & 0,000 & 0,05 & Menolak Ho \\
$\boldsymbol{\varepsilon}_{\mathbf{1}}$ & 0,121 & - & - & - \\
$\boldsymbol{\varepsilon}_{\mathbf{2}}$ & 0,033 & - & - & - \\
\hline
\end{tabular}

Struktur hubungan pada penelitian ini nampak pada Gambar 1.

$\varepsilon_{2}$

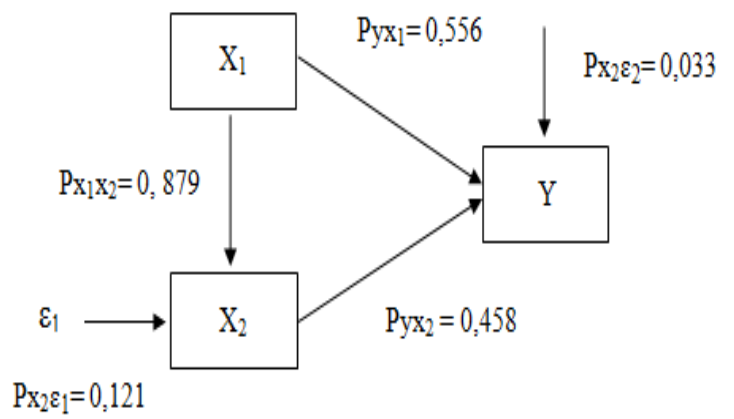

Gambar 1. Struktur hubungan pengaruh $X_{1}$ dan $X_{2}$ terhadap $Y$ 


\begin{tabular}{lcc} 
Keterangan & Besar & Persentase \\
\hline $\begin{array}{l}\text { Besar pengaruh langsung } \mathbf{X}_{\mathbf{1}} \text { terhadap } \\
\mathbf{Y}\end{array}$ & 0,556 & $55,6 \%$ \\
$\begin{array}{l}\text { Besar pengaruh tidak langsung } \mathbf{X}_{\mathbf{1}} \\
\text { terhadap } \mathbf{Y} \text { melalui } \mathbf{X}_{\mathbf{2}}\end{array}$ & 0,402 & $40,2 \%$ \\
$\begin{array}{l}\text { Besar pengaruh total } \mathbf{X}_{\mathbf{1}} \text { terhadap } \mathbf{Y} \\
\text { Besar pengaruh langsung } \mathbf{X}_{\mathbf{2}} \text { terhadap }\end{array}$ & 0,779 & $77,9 \%$ \\
$\mathbf{Y}$ & 0,458 & $45,8 \%$ \\
$\begin{array}{l}\text { Besar pengaruh total } \mathbf{X}_{\mathbf{1}} \text { dan } \mathbf{X}_{\mathbf{2}} \\
\text { terhadap } \mathbf{Y}\end{array}$ & 0,967 & $96,7 \%$ \\
$\begin{array}{l}\text { Besar pengaruh lain terhadap } \mathbf{Y} \\
\text { Total }\end{array}$ & 0,033 & $3,3 \%$ \\
\hline
\end{tabular}
tabel 2 .

Sumbangan pengaruh $X_{1}$ dan $X_{2}$ terhadap $Y$ di Hotel Gran Surya Seririt, nampak pada

Berdasarkan penelitian yang dilakukan, maka diperoleh temuan bahwa variabel $X_{1}$ berpengaruh terhadap $Y$ di Hotel Gran Surya. Hal tersebut sejalan dengan pendapat Rivai (2004) yang menyatakan bahwa semakin kuat motivasi kerja maka kinerja karyawan akan semakin tinggi. pernyataan tersebut didukung oleh penelitian empirik dari Amalia (2018). Motivasi kerja sangat membantu dalam mencapai target perusahaan. Apabila karyawan mendapatkan motivasi yang kuat maka karyawan tersebut akan terdorong untuk bekerja lebih baik sehingga berdampak terhadap kinerja karyawan. Rendahnya motivasi kerja di Hotel Gran Surya dapat dilihat dari penghargaan yang diberikan kepada karyawan yang masih sangat sedikit dan hubungan antar karyawan yang masih kurang baik dalam bekerjasama. Oleh karena itu, pihak hotel harus memperhatikan motivasi kerja untuk meningkatkan kualitas kerja dan mengoptimalkan kineja karyawan untuk mencapai tujuan perusahaan.

Hasil penelitian selanjutnya yang diperoleh adalah variabel $X_{2}$ berpengaruh secara positif dan signifikan terhadap Y di Hotel Gran Surya. Hal ini sejalan dengan pendapat Martoyo (2006) yang menjelaskan bahwa semakin baik kemampuan kerja karyawan maka semakin tinggi pula kinerja karyawan. Pernyataan tersebut didukung oleh penelitian empirik dari Arini (2015). Kemampuan kerja sangat penting diperhatikan untuk meningkatkan produktivitas dalam bekerja. Hal tersebut akan mampu mendorong pihak hotel dalam mencapai tujuan perusahaan yang telah ditetapkan. Rendahnya kemampuan kerja dapat dilihat dari kemampuan intelektual dan emosional karyawan. Pada kemampuan intelektual, karyawan belum memiliki inisiatif dalam mengevaluasi dan meningkatkan kinerja dengan strategistrategi baru. Penguasaan informasi karyawan masih kurang sehingga informasi yang diberikan kurang cepat dan tepat yang menyebabkan pelayanan belum optimal sedangkan dalam kemampuan emosional karyawan masih belum percaya diri dalam berkomunikasi berbahasa Inggris dan keahlian lain yang dibutuhkan dalam bidangnya sehingga banyak terjadi keluhan dari wisatawan. Sumbangan pengaruh $\mathrm{X}_{2}$ terhadap $\mathrm{Y}$ lebih kecil dibandingkan dengan $X_{1}$. Hal tersebut dikarenakan karyawan lebih ingin dihargai dalam pekerjaannya dengan memberikan penghargaan dan memiliki kerjasama tim yang baik sebagai salah satu 
bagian dari motivasi kerja. Kemampuan kerja tentunya memberikan kesempatan karyawan dalam berkarya secara totalitas.

Penelitian selanjutnya diperoleh hasil bahwa variabel $X_{1}$ berpengaruh secara positif dan signifikan terhadap $X_{2}$ di Hotel Gran Surya. Hal ini sejalan dengan Blumberg (1982) yang menyatakan karyawan yang memiliki motivasi akan berpengaruh terhadap kemampuan yang dimilikinya dan sebaliknya. Dengan adanya motivasi kerja tentunya tercipta semangat karyawan dalam memaksimalkan kinerja. Peningkatan kinerja yang terjadi akan melatih kemampuan karyawan untuk profesional dalam melayani tamu hotel. Pihak hotel hendaknya memperhatikan motivasi dan kemampuan kerja sehingga evaluasi yang telah dilakukan dapat mengoptimalkan tujuan perusahaan. Motivasi kerja perlu ditingkatkan untuk menumbuhkan rasa semangat bekerja sehingga meningkatkan kemampuan karyawan.

Hasil penelitian selanjutnya menunjukan bahwa variabel $X_{1}$ berpengaruh secara positif dan signifikan terhadap $\mathrm{Y}$ melalui $\mathrm{X}_{2}$ di Hotel Gran Surya. Hal ini sejalan dengan yang disampaikan oleh Sulistiyani (2003) menyatakan apabila motivasi tinggi kemudian didukung oleh skill yang baik maka kinerja pegawai juga tinggi dan sebaliknya. Pernyataan tersebut didukung oleh penelitian empirik dari Muliharta (2015). Hasil penelitian ini dibuktikan dari kurangnya penghargaan yang diberikan, suasana kerja yang kurang kondusif dan kurangnya solidaritas dalam tim. Selain itu, keinginan karyawan untuk saling membantu dan melayani sangat kurang sehingga hal tersebut menyebabkan kondisi dan lingkungan kerja yang kurang kondusif dan seharusnya karyawan mampu beradaptasi dalam berbagai situasi dan melihat dari setiap perubahan dan kebutuhan dari wisatawan maupun rekan kerja. Oleh karena itu, pihak hotel harus memperhatikan kedua variabel ini yaitu motivasi dan kemampuan kerja untuk meningkatkan kinerja. Pengaruh langsung $X_{1}$ terhadap $Y>$ dibandingkan pengaruh tidak langsung melalui $X_{2}$. Hal tersebut dikarenakan para karyawan Hotel Gran Surya menganggap bahwa pemberian penghargaan dan suasana yang kondusif akan memotivasi para karyawan untuk dapat lebih bekerja secara optimal dibandingkan dengan pemberian pelatihan untuk meningkatkan kemampuan karyawan dalam melayani tamu hotel. Pemberian motivasi kerja yang tepat akan akan menciptakan manajemen hotel yang sesuai dengan standar dan memenuhi kebutuhan karyawan untuk bekerja secara maksimal. Hal tersebut akan memotivasi karyawan dalam meningkatkan kinerja hotel.

Penelitian ini memberikan impikasi bahwa motivasi kerja sangat penting untuk menunjang kinerja karyawan. Oleh karena itu, pihak hotel hendaknya memperbaiki hal-hal yang berkaitan dengan motivasi kerja. Upaya yang telah dilakukan oleh pihak hotel diantaranya pemberian gaji dan insentif dan melakukan pengawasan kepada bawahannya. Upaya tersebut dalam penerapannya belum memperoleh hasil yang optimal sehingga diperlukan upaya-upaya lain untuk meningkatkan motivasi kerja seperti memberikan penghargaan kinerja secara rutin dan memberikan apresiasi kepada karyawan yang mencapai target setiap setahun sekali serta menciptakan suasana kerja yang nyaman dengan mengadakan kegiatan untuk meningkatkan keakraban dan rasa saling memiliki serta kekeluargaan karyawan secara rutin. Perusahaan juga dapat merancang program rutin lain untuk memacu motivasi karyawan seperti melakukan konsultasi rencana pengembangan posisi dan karir ke depan bagi karyawan, mendorong suasana dan atmosfer kerja yang positif dan kondusif serta hubungan sosial yang baik, membangun sistem komunikasi yang baik dan terbuka serta membangun kepercayaan antara karyawan dan perusahaan atau manajemen.

Kemampuan kerja memiliki peran penting dalam meningkatkan kinerja karyawan di Hotel Gran Surya. Kemampuan kerja sangat diperlukan untuk meningkatkan produktivitas karyawan dalam bekerja. Oleh karena itu, pihak hotel hendaknya meningkatkan kemampuan kerja dengan berbagai upaya. Upaya yang telah dilakukan oleh pihak hotel dinantaranya melakukan evaluasi kemampuan karyawan setiap satu tahun sekali dan melakukan training perusahaan hanya pada saat karyawan memasuki tempat kerja. Upaya tersebut dinilai kurang optimal dalam meningkatkan kemampuan perusahaan sehingga perusahaan perlu melaksanakan evaluasi kemampuan karyawan. Peningkatan kemampuan intelektual karyawan perlu dilakukan dengan mengasah kembali penggunaan Bahasa Inggris, product 
knowledge dan menangani keluhan dari tamu setidaknya dilaksanakan setiap satu bulan sekali dan melatih kemampuan bisa dilaksanakan lebih sering dan rutin misalnya tiga bulan sekali untuk meningkatkan profesionalisme bekerja dari karyawan. Pada kamampuan emosional, perusahaan perlu melatih kesigapan dan keramahtamahan dalam bekerja dengan melaksanakan upaya penilaian kepada karyawan dalam melayani wisatawan yang berkunjung. Peningkatan kemampuan sosial juga perlu ditingkatkan melalui pembentukan karakter, sikap dan perilaku dalam bekerjasama secara tim. Hal ini dapat dilakukan dengan melaksanakan kegiatan yang mengandung unsur kerjasama dan interaksi bersama sehingga pihak manajemen perusahaan mengetahui kinerja karyawan dalam kemampuan sosial yang dimiliki.

Pemberian motivasi yang tepat akan menentukan bagaimana peningkatan kemampuan kerja karyawan untuk lebih optimal dan profesional. Oleh karena itu, pihak hotel hendaknya melakukan pembaharuan sehingga karyawan mampu memberikan kontribusi terbesarnya kepada perusahaan, misalnya dengan pemberian bonus setiap target penjualan, diperkenalkan sebagai karyawan terbaik setiap bulan dan mengadakan training rutin setiap tiga bulan sekali.

Motivasi kerja yang tinggi akan mengoptimalkan kinerja karyawan. Peningkatan kinerja membantu perkembangan dalam kemampuan karyawan menangani tamu hotel, keluhan dan pemberian informasi secara profesional. Oleh karena itu, pihak hotel hendaknya melakukan upaya dalam memaksimalkan kedua variabel ini yaitu motivasi dan kemampuan kerja untuk meningkatkan kinerja.

\section{Simpulan dan Saran}

Berdasarkan hasil dan pembahasan yang telah dilakukan, maka dapat ditarik beberapa kesimpulan sebagai berikut. 1) $X_{1}$ berpengaruh secara positif dan signifikan terhadap Y di Hotel Gran Surya. Motivasi kerja sangat membantu dalam mencapai target perusahaan. Apabila karyawan mendapatkan motivasi yang kuat maka karyawan tersebut akan mendorong mereka dalam menyelesaikan beban dengan baik sehingga berdampak terhadap kinerja karyawan. Pihak hotel harus memperhatikan motivasi kerja untuk meningkatkan kualitas kerja dan mengoptimalkan kineja karyawan untuk mencapai tujuan perusahaan, 2) $X_{2}$ berpengaruh secara positif dan signifikan terhadap $Y$ di Hotel Gran Surya. Kemampuan kerja sangat penting diperhatikan untuk meningkatkan produktivitas dalam bekerja. Hal tersebut akan mampu mendorong pihak hotel dalam menggapai segala target yang ditetapkan hotel. Maka pihak hotel hendaknya meningkatkan kemampuan kerja karena memberikan kesempatan karyawan dalam berkarya secara totalitas. 3) $X_{1}$ berpengaruh secara positif dan signifikan terhadap $X_{2}$ di Hotel Gran Surya. Dengan adanya motivasi kerja tentunya tercipta semangat karyawan dalam memaksimalkan kinerja. Peningkatan kinerja yang terjadi akan melatih kemampuan karyawan untuk profesional dalam melayani tamu hotel. Oleh karena itu, pihak hotel hendaknya memperhatikan motivasi dan kemampuan kerja sehingga evaluasi yang telah dilakukan dapat mengoptimalkan tujuan perusahaan. 4) $X_{1}$ berpengaruh secara positif dan signifikan terhadap $\mathrm{Y}$ melalui $\mathrm{X}_{2}$ di Hotel Gran Surya. Peningkatan kinerja dapat dilakukan dengan mengoptimalan motivasi kerja dan kemampuan kerja. Pemberian motivasi kerja yang tepat akan menciptakan manajemen hotel yang sesuai dengan standar dan dengan hal tersebut mampu meningkatkan kemampuan kerja karyawan untuk lebih profesional.

Saran yang dapat dianjurkan sebagai berikut. 1) Bagi pihak manajemen Hotel Gran Surya agar meningkatkan kinerja karyawan dengan memperhatikan motivasi kerja dan kemampuan kerja. Motivasi kerja dan kemampuan kerja yang tercipta sangat tergantung dengan kebijakan manajemen hotel dan SDM yang dimiliki. Untuk memaksimalkan hal tersebut pihak hotel perlu melakukan upaya evaluasi terhadap permasalahan internal. 2) Bagi peneliti selanjutnya, diharapkan untuk dapat memperluas penelitian ini dengan menambahkan sampel agar mampu menguji variabel bebas lainnya yang diduga kuat dapat memengaruhi variabel terikat dalam penelitian ini. 


\section{Daftar Pustaka}

Amalia, 2018. Pengaruh lingkungan kerja dan motivasi kerja terhadap kinerja karyawan pegawai dinas tenaga kerja dan sosial kabupaten sleman. Pengaruh lingkungan kerya (Nurul R.A).

Arini. 2015. Pengaruh Kemampuan Kerja dan Motivasi Kerja Terhadap Kinerja Karyawan di PT. Perkebunan Nusantara. Jurnal Administrasi Bisnis (JAB). Vol. 22 No. 1.

Blumberg, M and C. D. Pringle. 1982. The Missing Opportunity in Organization Research: Some Implications for A Theory of Work Performance. Academy of Management Review. October. P. 560-580.

Brantas. 2009. Dasar-Dasar Manajemen. Bandung: Alfabeta.

Bangun, Wilson. 2012. Manajemen Sumber Daya Manusia. Jakarta: Erlangga.

Dharma, Agus. 2003. Manajemen Supervisi: Petunjuk Praktis Bagi Para Supervisior. Edisi Revisi. Cetakan Kelima. Jakarta: Raja Grafindo Persada.

Ghozali, Imam dan Fuad. 2008. Structuran Equation Modeling. Semarang: Badan Penerbit Universitas Diponegoro.

Gibson. 2004. Organisasi Perilaku Struktur Proses. Terjemahan. Edisi V. Jakarta: Penerbit Erlangga.

Gomes, Faustino Cardoso. 2003. Manajemen Sumber Daya Manusia. Edisi Kedua. Penerbit Andi Offset, Yogjakarta.

Handoko, T.Hani. 2013. Manajemen. Edisi kedua. BPFE Yogjakarta.

Hasibuan, Malayu. 2001. Manajemen Sumber Daya Manusia: pengertian dasar, pengertian, dan Masalah. Jakarta : PT. Toko Gunung Agung.

Hasibuan, S.P Malayu. 2005. Manajemen Sumber Daya Manusia. Edisi Revisi. Jakarta: Bumi Aksara.

Hays,W.L. 1969. Stastics. London: Holt, Rinchart\&Winston.

Kristiani. 2013. Pengaruh Kemampuan Kerja dan Motivasi Kerja Terhadap Kinerja Karyawan. Diponegoro Journal Of Social and Politic. Hal 1-7.

Martoyo, Susilo. 2006. Manajemen Sumber Daya Manusia. Edisi Kelima. Yogjakarta: BPFEYogjakarta.

Muliharta, Ketut. 2015. Pengaruh kemampuan kerja dan motivasi kerja terhadap kinerja karyawan pada hotel puri bagus lovina. Jurnal jurusan pendidikan ekonomi (JJPE) Vol. 5 No. 1.

Rivai, Veithzal. 2004. Manajemen Sumber Daya Manusia Untuk Perusahaan. Jakarta: PT. Raja Grafindo Persada.

Robbins, S. 2002. Perilaku Organisasi. Jakarta: Selemba Empat. 
Robbins, S. 2006. Perilaku Organisasi. Alih Bahasa: Drs. Benjamin Molan. Edisi Bahasa Indonesia. Klaten: PT. Intan Sejati.

Robbins, S. 2008. Perilaku Organisasi, Jilid I dan II, alih Bahasa: Hadyana Pujaatmaja. Jakarta: Prenhallindo.

Robbinss Stephen P, 2011, Organizational Behavior (Terjemahan) Jilid 1, Edisi Kedelapan, PT. Bhuana Ilmu Populer, Jakarta.

Sugiyono, 2007, Metodologi Penelitian Bisnis, PT. Gramedia, Jakarta

Sugiyono, 2013, Statistika Untuk Penelitian, Penerbit CV. Alfabeta, Bandung.

Sugiyono, 2014. Metode Penelitian Bisnis. Bandung: Afabeta

Sulistiyani, Teguh Ambar. 2003. Manajemen dan Sumber Daya Manusia : Konsep Teori dan Pengembangan Dalam Konteks Organisasi Publik. Yogyakarta : Graha Ilmu.

Suranta, Sri. 2002. Dampak Motivasi Karyawan Pada Hubungan Antara Gaya Kepemimpinan dengan Kinerja Karyawan Perusahaan Bisnis. Empirik. Vol 15. No 2.

Sutrisno, Edy. 2009. Manajemen Sumber Daya Manusia, Edisi Pertama, Cetakan pertama, Jakarta : prenada media.

Sutrisno, Edy. 2010 Manajemen Sumber Daya Manusia. PT. Predana Media Group. Jakarta.

Tampi. 2014. Pengaruh Gaya Kepemimpinan dan Motivasi Terhadap Kinerja Karyawan Pada PT. Bank Negara Indonesia, Tbk. Jurnal Acta Diurna. Vol. 3 No.4.

Wirawan. 2009. Evaluasi Kinerja Sumber Daya Manusia Teori Aplikasi dan Penelitian. Jakarta. Penerbit: Salemba Empat.

Wursanto Drs. 2003. Dasar-dasar Ilmu Organisasi. Yogjakarta: Andi Offset. 